\title{
Combined Photothermal and lonizing Radiation Sensitization of Triple-Negative Breast Cancer Using Triangular Silver Nanoparticles
}

This article was published in the following Dove Press journal: International Journal of Nanomedicine

\author{
James Sears' \\ Jessica Swanner' \\ Cale D Fahrenholtz (DD ${ }^{1,2}$ \\ Christina Snyder' \\ Monica Rohde' \\ Nicole Levi-Polyachenko ${ }^{3,4}$ \\ Ravi Singh (iD) ${ }^{1,4}$ \\ 'Department of Cancer Biology, Wake \\ Forest School of Medicine, Winston- \\ Salem, NC, USA; ${ }^{2}$ Department of Basic \\ Pharmaceutical Sciences, Fred Wilson \\ School of Pharmacy, High Point \\ University, High Point, NC, 27268, USA; \\ ${ }^{3}$ Department of Plastic Surgery and \\ Reconstructive Medicine, Wake Forest \\ School of Medicine, Winston-Salem, NC, \\ USA; ${ }^{4}$ Comprehensive Cancer Center, \\ Wake Forest Baptist Medical Center, \\ Winston-Salem, NC, USA
}

Background: Ionizing radiation (IR) is commonly used in triple-negative breast cancer (TNBC) treatment regimens. However, off-target toxicity affecting normal tissue and grueling treatment regimens remain major limitations. Hyperthermia is one of the greatest IR sensitizers, but only if heat is administered simultaneously or immediately prior to ionizing radiation. Difficulty in co-localizing ionizing radiation (IR) in rapid succession with hyperthermia, and confining treatment to the tumor have hindered widespread clinical adoption of combined thermoradiation treatment. Metal nanoparticle-based approaches to IR sensitization and photothermal heat generation may aid in overcoming these issues and improve treatment specificity.

Methods: We assessed the potential to selectively treat MDA-MB-231 TNBC cells without affecting non-malignant MCF-10A breast cells using a multimodal approach based upon combined photothermal therapy, IR sensitization, and specific cytotoxicity using triangular silver nanoparticles (TAgNPs) with peak absorbance in the near-infrared light (NIR) spectrum.

Results: We found that TAgNP-mediated photothermal therapy and radiosensitization offer a high degree of specificity for treatment of TNBC without affecting non-malignant mammary epithelial cells.

Discussion: If given at a high enough dose, IR, heat, or TAgNPs alone could be sufficient for tumor treatment. However, when the dose of one or all of these modalities increases, offtarget effects also increase. The challenge lies in identifying the minimal doses of each individual treatment such that when combined they provide maximum selectivity for treatment of TNBC cells with minimum off-target effects on non-malignant breast cells. Our results provide proof of concept that this combination is highly selective for TNBC cells while sparing non-malignant mammary epithelial cells. This treatment would be particularly important for patients undergoing breast conservation therapy and for treatment of invasive tumor margins near the periphery where each individual treatment might be at a subtherapeutic level.

Keywords: radiation sensitizer, hyperthermia, nanoparticle, cancer, laser

\section{Introduction}

Triple-negative breast cancer (TNBC) is an aggressive, poor prognosis subtype that accounts for approximately $15 \%$ of all breast cancer cases. ${ }^{1,2}$ Locoregional recurrence is more frequent for TNBC patients compared to patients with other subtypes of breast cancer, ${ }^{3,4}$ necessitating additional treatment and increasing the likelihood of distant metastases and death. ${ }^{5}$ Ionizing radiation (IR) in combination with breast
Correspondence: Ravi Singh

Department of Cancer Biology, Wake Forest School of Medicine, Medical

Center Blvd., Winston-Salem, NC, 27I57, USA

Tel +336-7I3-4434

Fax +336-716-0255

Email rasingh@wakehealth.edu
International Journal of Nanomedicine 2021:16 85I-865

submit your manuscript

(c) (i) (5) 2021 Sears et al. This work is published and licensed by Dove Medical Press Limited. The full terms of this license are available at https://www.dovepress.com/terms.php cc) you hereby accept the Terms. Non-commercial uses of the work are permitted without any further permission from Dove Medical Press Limited, provided the work is properly attributed. For permission for commercial use of this work, please see paragraphs 4.2 and 5 of our Terms (https://www.dovepress.com/terms.php). 
conservation surgery or mastectomy, and systemic chemotherapy, is a crucial component of the standard of care treatment for TNBC patients. ${ }^{6}$ Adjuvant IR treatment improves outcomes following lumpectomy or mastectomy in patients with large $(>5 \mathrm{~cm})$ tumors, positive tumor margins, or positive axillary nodes. ${ }^{7}$ Multiple retrospective analyses indicate that patients with TNBC tumors who received IR as part of breast conservation therapy had decreased risk of locoregional recurrence, thereby avoiding mastectomy. ${ }^{3,8-11}$ Whole-breast irradiation typically involves delivery of 40-50 Gy in 15-25 fractions over 3-5 weeks. This 3-5 week commitment for radiation therapy requires women to commute for treatment multiple times per week, take time off from work, and potentially make additional arrangements for childcare. The increased burden may lead women to opt out of radiation all together, even when radiotherapy is the best option for overall survival. ${ }^{12-14}$ Furthermore, IR treatment is not without significant side effects. Therapeutic exposure to IR can lead to cardiotoxicity, ${ }^{15}$ skin toxicity, ${ }^{16}$ and secondary malignancies. ${ }^{17}$ Because some women are electing to forgo the benefit of IR due to toxicity risk and personal or societal constraints, new strategies are needed to reduce both the dose and frequency of IR exposure in women being treated for breast cancer.

Techniques currently employed to help minimize exposure of normal breast and lymph tissue to radiation include intensity modulated radiation therapy, deep-inspiration breath hold, and hypofractionation, but risk of acute and late adverse events are still considerable. ${ }^{18}$ There is a lack of evidence demonstrating that accelerated courses using high dose radiation improve long-term survival outcomes for breast cancer patients, including those with evidence of residual disease after lumpectomy. ${ }^{19}$ Partial breast irradiation may be an option for some women, but this does not reduce treatment duration and has not been shown to improve patient outcomes compared to whole breast irradiation. $^{20}$

Radiosensitizers may increase the efficacy of IR, allowing for fewer doses of radiation and reducing toxicity to surrounding healthy tissue. Substantial progress has been made in the development of radiosensitizers composed of high atomic number $(\mathrm{Z})$ nanomaterials including silver, ${ }^{21-23}$ gold, ${ }^{24-27}$ gadolinium, ${ }^{28}$ and hafnium oxide. ${ }^{29}$ Notably, clinical trials using hafnium oxide or gadolinium nanoparticles as radiation dose enhancers clearly demonstrated the potential of high atomic number $(\mathrm{Z})$ nanomaterials to increase patient responses. ${ }^{28,29}$ The dose enhancing effects of high $\mathrm{Z}$ nanoparticles are due in part to the increased interaction cross-section of high $\mathrm{Z}$ materials with IR. This then generates photoelectric and Compton scattering events that increase the production of secondary electrons, which in turn enhance therapeutic effects. However, biochemical mechanisms can also influence radiosensitization by nanoparticles. ${ }^{30,31}$ We previously found that spherical silver nanoparticles (AgNPs) were selectively cytotoxic to TNBC cells and tumors with minimal toxicity to non-malignant cells and tissues following intratumoral or intravenous injection. ${ }^{23,32}$ The sensitivity of TNBC cells to AgNPs was determined to be due to a lethal combination of DNA damage, protein oxidation, and induction of endoplasmic reticulum (ER) stress in TNBC following AgNP treatment. ${ }^{32}$ Notably, similar damage following AgNP exposure was not observed in models of the normal mammary epithelium, and studies by others supported this finding. ${ }^{33}$ Exposure to AgNPs also sensitized TNBC cells to IR without simultaneously sensitizing normal mammary epithelial cells to IR. ${ }^{23}$ AgNPs can be infused into tumors by direct injection, which makes them particularly attractive for use as radiosensitizers in the context of breast conservation therapy.

In addition to radiosensitization, metal nanoparticles have been developed to allow for rapid generation of localized heat within tumors following exposure to nearinfrared light (NIR; wavelengths in the range of 650 to $1100 \mathrm{~nm}$ ), a technique called photothermal therapy. ${ }^{34}$ The use of NIR light for photothermal treatments is ideal for cancer therapy due to increased penetration of NIR wavelengths through body tissues compared to wavelengths in other parts of the optical spectrum. ${ }^{35}$ In the breast, the mean free path for absorption of photons in the NIR range is over $15 \mathrm{~cm}$, but that for scattering is about $0.001 \mathrm{~cm}^{36}$ Thus, NIR photons are scattered in breast tissue more frequently than they are absorbed, leading to diffusion, loss of energy density, and heating of a region of tissue well outside the initial focal area of the NIR beam. Because the scattering coefficient decreases with wavelength, use of longer wavelengths $(>950 \mathrm{~nm})$ of NIR are desirable to increase directionality. On its own, heat generation within a tumor can be therapeutic provided the temperature is high enough for sufficient duration, resulting in cancer cell death. ${ }^{37}$ Introduction of NIR absorptive nanoparticles into the tumor can increase both the rate and amount of heat deposited into the tumor compared to NIR irradiation alone. ${ }^{37}$ The efficiency of light to heat conversion is greatest when metal nanoparticles are excited by 
wavelengths of light corresponding to their plasmon resonance, a collective oscillation of excited electrons following exposure to light. The plasmon resonance is tuned to a specific wavelength based upon the size and shape of nanoparticles. Most silver nanoparticles used in medicine are spherical and have a plasmon resonance between 410 $\mathrm{nm}$ and $450 \mathrm{~nm}$. To enable peak absorbance in the NIR, it is necessary to use silver nanoparticles with an anisotropic shape such as a triangle, which can shift the peak absorbance to the NIR range. ${ }^{38}$

The challenges of confining therapeutic doses of heat to tumors and sparing normal tissue from the effects of heat diffusion away from the targeted area have limited the impact of nanoparticle-mediated photothermal treatment as a monotherapy. ${ }^{37}$ However, hyperthermia is also one of the greatest dose enhancers of ionizing radiation. ${ }^{39-41}$ The combination of mild hyperthermia and IR is synergistic, but the temporal relationship between heat delivery and radiation exposure is a critical factor. Factors including induction of a protective heat shock response, caused by sub-lethal heat exposure can reduce efficacy of IR. ${ }^{42,43}$ To avoid this, hyperthermia must be delivered simultaneously or immediately before IR to maximize radiosensitization. ${ }^{44}$

The difficulty of heating tumors specifically and the need to perform heating and radiotherapy in rapid sequence have hampered broad clinical application of combined thermoradiation treatments. ${ }^{45}$ It may be possible to overcome these issues using nanoparticle-mediated thermoradiation sensitization. ${ }^{25}$ Therefore, we performed studies to assess the potential to selectively treat TNBC cells using a multimodal approach based upon combined photothermal therapy, IR sensitization, and TNBC specific cytotoxicity using triangular AgNPs (TAgNPs) with peak absorbance in the NIR spectrum. We evaluated the heatgenerating capacity of TAgNPs in response to NIR exposure, and optimized doses of TAgNPs, NIR, and IR to maximize cytotoxicity toward TNBC cells and minimize off target effects on non-malignant mammary epithelial cells. Our results provide proof of concept evidence that the combination of TAgNPs, NIR, and IR is effective for the treatment of TNBC cells while sparing non-malignant mammary epithelial cells.

\section{Materials and Methods}

\section{Materials}

TAgNPs stabilized with polyvinylpyrrolidone with a plasmon resonance near $950 \mathrm{~nm}$ were purchased from
nanoComposix (San Diego, CA, USA; Lot Number KJW2188) as a $1 \mathrm{mg} / \mathrm{mL}$ stock of TAgNPs in a $5 \mathrm{mM}$, pH 9.3 sodium borate buffer. Prior to use of TAgNPs, the sodium borate buffer was exchanged with sterile, Type 1 water using a spin column. Briefly, $500 \mu \mathrm{L}$ of a $1 \mathrm{mg} / \mathrm{mL}$ dispersion of the TAgNP stock was added to $20 \mathrm{~mL}$ of distilled water Vivaspin column with a molecular weight cut-off of $30 \mathrm{kD}$ and then centrifuged at $14,590 \times \mathrm{g}$ for 20 minutes, which concentrated the solution to $1 \mathrm{~mL}$. The concentrated nanoparticle solution was diluted in $20 \mathrm{~mL}$ of Type 1 water, and the process was repeated until three washes were completed. The final nanoparticle solution volume was between $500 \mu \mathrm{L}$ and $1 \mathrm{~mL}$. The optical absorbance of TAgNPs in Type 1 water was determined using a Spectronic 200 spectrophotometer (Thermo Scientific, Waltham, Ma, USA). Concentration of the TAgNP suspension was determined by comparison of absorption peak to a standard curved prepared from the initial stock solution. The washed nanoparticles were stored at $4{ }^{\circ} \mathrm{C}$ in the dark and used for subsequent experiments within $6 \mathrm{~h}$ of preparation.

\section{Dynamic Light Scattering}

Hydrodynamic diameter (size) and $\zeta$-potential were determined using a Zetasizer Nano ZS90 (Malvern Instruments, Malvern, UK) at $25^{\circ} \mathrm{C}$. For size measurement, TAgNP solutions were diluted in phosphate-buffered saline (PBS), pH 7.4 in a disposable plastic cuvette (Sarstedt, Newton, NC, USA). The $\zeta$-potential of TAgNPs was measured in a 1:10 dilution of PBS in water using a disposable folded Zetazsizer capillary cell (Malvern Instruments).

\section{Assessment of Photothermal Heating}

TAgNPs were dispersed in $0.5 \mathrm{~mL}$ of DMEM in a 48 well tissue culture plate and exposed to a $970 \mathrm{~nm}$ laser $(\mathrm{K}$ Cube Laser; Summus Medical Laser, LLC, Franklin, TN) at the concentration, power, and durations indicated in the figure legends. The laser spot size was adjusted to completely cover the surface of the well. At least one empty well was placed between replicates, forming a checkerboard pattern on the plate to prevent heat transfer to neighboring wells. The initial temperate and final temperature immediately after laser exposure was measured using a Fluke 714 thermocouple calibrator and type $\mathrm{K}$ thermocouple $80 \mathrm{PK}-1$ bead probe wire thermocouple (Fluke, Everett, WA). 


\section{Cell Culture}

MCF-10A and MDA-MB-231 cells were purchased from ATCC (American Type Culture Collection Manassas, VA, USA). MCF-10A cells were grown in DMEM/F12 supplemented with penicillin, streptomycin, $2 \mathrm{mM}$ L-glutamine, $20 \mathrm{ng} / \mathrm{mL}$ epidermal growth factor, $0.5 \mu \mathrm{g} / \mathrm{mL}$ hydrocortisone, and $100 \mathrm{ng} / \mathrm{mL}$ cholera toxin. MDA-MB-231 cells were grown in DMEM supplemented with $10 \%$ fetal bovine serum (v/v), $2 \mathrm{mM}$ L-glutamine, $250 \mathrm{U} / \mathrm{mL}$ penicillin, and $250 \mu \mathrm{g} / \mathrm{mL}$ streptomycin. All cells were maintained in a $37^{\circ} \mathrm{C}$, humidified incubator in a $5 \% \mathrm{CO}_{2}$ atmosphere. All cell lines were verified to be free from mycoplasma contamination by testing using the MycoAlert Mycoplasma Detection Kit (Lonza, Basel, Switzerland).

\section{MTT Assay}

MDA-MB-231 and MCF-10A cells were seeded at a density of $7 \times 10^{3}$ cells per well in 96-well plate. The following day, cells were treated with increasing concentrations of TAgNPs in $200 \mu \mathrm{L}$ volume for 72 hours. Cells were washed in PBS. Next, $200 \mu \mathrm{L}$ of media containing $0.5 \mathrm{mg} / \mathrm{mL} 3$-(4,5-dimethylthiazol-2-yl)-2,5-diphenyltetrazolium bromide (MTT; Sigma-Aldrich, St. Louis, MO. USA) was added and incubated for $1 \mathrm{~h}$ at $37^{\circ} \mathrm{C}$. Next, medium was aspirated and crystals were solubilized with dimethyl sulfoxide (Sigma-Aldrich) and absorbance read using a Molecular Devices (San Jose, CA, USA) Emax Precision Microplate Reader at $560 \mathrm{~nm}$ and corrected for background at $650 \mathrm{~nm}$.

\section{Clonogenic Assay}

MDA-MB-231 and MCF-10A cell lines were plated at a density of 300 cells $/ \mathrm{mL}$ in 6 -well tissue culture plates and allowed to adhere overnight. The following day cells were treated with increasing concentrations of TAgNPs in $3.5 \mathrm{~mL}$ of normal growth medium. After 24 hours, the cells were washed with PBS to remove TAgNPs and media was exchanged every 72 hours. Fourteen days after TAgNP treatment media was removed and cells were washed and fixed with a solution of methanol, glacial acetic acid, and water (1:1:8 volume ratios, respectively). The cells were then stained with crystal violet, rinsed in water, and colonies of at least 50 cells were counted under a dissecting microscope.

\section{Flow Cytometry Apoptosis Analysis}

MDA-MB-231 and MCF-10A cells were plated at a density of $7.5 \times 10^{5}$ in $10 \mathrm{~cm}$ tissue culture plates and allowed to adhere overnight. Cells were then treated with $25 \mu \mathrm{g} / \mathrm{mL}$ of TAgNPs or vehicle in $14 \mathrm{~mL}$ of media. After 72 hours, cells were washed twice with PBS, trypsinized, and resuspended in their respective media. Cells were then pelleted by centrifugation at $320 \mathrm{x}$ g for 5 minutes. Cells were resuspended in ice cold PBS and pelleted again by centrifugation at $320 \mathrm{x}$ g for 5 minutes. Allophycocyanin conjugated Annexin $\mathrm{V}$ and propidium iodide staining was performed per the manufacturer's instructions (BD Biosciences, San Jose, CA, USA). Labeled cells were analyzed on the Accuri6 Flow Cytometer (BD Biosciences). Analysis of data was performed using FCS Express version 7 (De Novo Software, Glendale, CA, USA). Unstained samples were included to control for any potential interference of AgNPs with flow cytometry. There was no detectable change in forward or side scatter, PI fluorescence, or APC fluorescence in the unstained samples, indicating that AgNPs did not interfere with the assay.

\section{Electron Microscopy}

A total of $5 \times 10^{5}$ cells/well were plated on 6-well plates and allowed to adhere for 24 hours at $37^{\circ} \mathrm{C}$ and $5 \% \mathrm{CO}_{2}$ atmosphere. The following day, media was aspirated and $3 \mathrm{~mL}$ of fresh media containing 0 or $100 \mu \mathrm{g} / \mathrm{mL}$ of TAgNPs was added and incubated for 3 hours in $37^{\circ} \mathrm{C}$ and $5 \% \mathrm{CO}_{2}$ atmosphere to enable time for uptake of the nanoparticles. The high dose of TAgNPs was used to increase the frequency of detection of TAgNPs in cells. The cells were then washed 3 times with ice cold PBS. PBS was removed and $0.5 \mathrm{~mL}$ of a $2.5 \%$ glutaraldehyde solution was added, and cells were incubated overnight at $4^{\circ} \mathrm{C}$. The glutaraldehyde solution was removed and cells were placed in $500 \mu \mathrm{L}$ of PBS. Cells were embedded in resin, cut into $80 \mathrm{~nm}$ sections, and placed on copper-coated Formvar $^{\circledR}$ grids by the Wake Forest Comprehensive Cancer Center Cell Imaging Shared Resource. The sections were imaged using a Tecnai Spirit transmission electron microscope (FEI, Hillsboro, OR, USA).

\section{Cytotoxicity of TAgNP-Mediated Photothermal Therapy}

MCF-10A and MDA-MB-231 cells were plated at a density of $1.2 \times 10^{4}$ cells/well in a checkerboard pattern 
on a 48-well plate and allowed to attach for 24 hours. The checkerboard plating minimizes off-target heating of nearby wells. After 24 hours, the media was replaced with media containing $0,6.25$, or $12.5 \mu \mathrm{g} / \mathrm{mL}$ TAgNP. Three hours later, cells were exposed to an NIR laser. Next, the cells were placed back in an incubator. After 72 hours, an MTT assay was performed as described above.

\section{Assessment of TAgNP-Mediated Sensitization to lonizing Radiation}

MDA-MB-231 and MCF-10A cells were plated in 6-well tissue culture dishes at a density of 300 cells/well. Cells were allowed to adhere overnight and media was replaced with fresh media containing TAgNPs. After 24 hours cells were washed twice with PBS to remove non-internalized AgNPs, and fresh media was added to each well. IR was administered using an orthovoltage $x$-ray source (GE, Niskayuna, NY, USA) with a current of $10 \mathrm{~mA}$, voltage of $300 \mathrm{kV}$, and a dose rate in water of $2.39 \mathrm{~Gy} / \mathrm{min}$ at the plate position, which was $30 \mathrm{~cm}$ from the $\mathrm{x}$-ray emitter. The cells were returned to the incubator and the media was replaced every 3 days. Two weeks later, a clonogenic assay was performed as described above.

\section{In vitro Effectiveness of TAgNP-Mediated Multimodal Therapy}

MDA-MB-231 and MCF-10A cell lines were plated at a density of $1.2 \times 10^{4}$ cells/well in a checkerboard pattern on a 48-well plate for each cell line and allowed to attach for 24 hours. Cells were treated with 0 or $12.5 \mu \mathrm{g} /$ TAgNPs in $0.5 \mathrm{~mL}$ of fresh media and incubated at $37^{\circ} \mathrm{C}$ in a $5 \% \mathrm{CO}_{2}$ atmosphere for $3 \mathrm{~h}$. One row of wells on each plate containing $12.5 \mu \mathrm{g} / \mathrm{mL}$ TAgNP and one row containing $0 \mu \mathrm{g} / \mathrm{mL}$ TAgNP were exposed to a NIR laser. The final temperature achieved for each treatment was determined in parallel using a separate plate, which contained cells in media treated with 0 or $12.5 \mu \mathrm{g} / \mathrm{mL}$ TAgNPs. One minute after each well was heated by NIR, the well was exposed to ionizing radiation as described above. The IR field size was reduced to cover a single well, and lead shielding was used to prevent radiation exposure in neighboring wells. After all wells were exposed to NIR and IR, the cells were then placed in an incubator at $37^{\circ} \mathrm{C}$ and $5 \% \mathrm{CO}_{2}$ atmosphere for 72 hours and cell viability was assessed by MTT assay.

\section{Statistical Analysis}

Analysis was performed as described in the figure legends using GraphPad Prism 8.0 software. Number of technical and biological replicates used for each experiment is included in the figure legends. Unless otherwise specified, all data are presented as the mean value \pm standard error of the mean. All experiments were replicated independently at least two times.

\section{Results}

The TAgNPs used in our study were stored in $5 \mathrm{mM}$ sodium borate, $\mathrm{pH} 9.3$, to stabilize the particle structure and to prevent etching, which can result in a blue shift in the plasmon resonance. Immediately before use, a buffer exchange was performed to remove sodium borate and transition the nanoparticles into type 1 water to eliminate any potentially toxic effects of the buffer or silver ions released during long-term storage. After performing the buffer exchange, physicochemical and heating characteristics were determined. The TAgNPs retained a triangular morphology with a nominal diameter of approximately 90 $\mathrm{nm}$ and exhibited a peak plasmon resonance of $933 \mathrm{~nm}$ (Figure 1A and B). Dynamic light scattering (DLS) analysis of TAgNPs showed that they were monodisperse with a hydrodynamic diameter of $93.33 \pm 1.63 \mathrm{~nm}$ (Figure 1C) and a $\zeta$-potential of $22.6 \pm 1.01 \mathrm{mV}$ (Figure 1D). After 24 hours in water, TAgNPs showed no noticeable change in size indicative of dissolution or aggregation over time, but the plasmon resonance peak shifted to $894.5 \mathrm{~nm}$, indicating etching of the particles (data not shown). To minimize etching effects due to storage in water, TAgNPs were used for experiments within $6 \mathrm{~h}$ following buffer exchange.

\section{TAgNPs Selectively Induce Apoptosis in TNBCs at Doses That Do Not Affect Non-Malignant Breast Cells}

Previous studies demonstrated the ability of spherical AgNPs to selectively kill TNBCs at doses that have no effect on non-malignant breast epithelial cells. ${ }^{23,32,33}$ To investigate if TAgNPs display a similar selective cytotoxicity, MDA-MB-231 cells (TNBC) and MCF-10A cells (non-malignant breast epithelial cells) were exposed to increasing doses of TAgNPs for $72 \mathrm{~h}$ and viability was assessed by MTT assay. MDA-MB-231 cells were significantly $(\mathrm{p}<0.05)$ more sensitive to TAgNP treatment at doses of $3.125 \mu \mathrm{g} / \mathrm{mL}$ or greater compared to the MCF10A cells (Figure 2A). At doses between $3.125 \mu \mathrm{g} / \mathrm{mL}$ and 


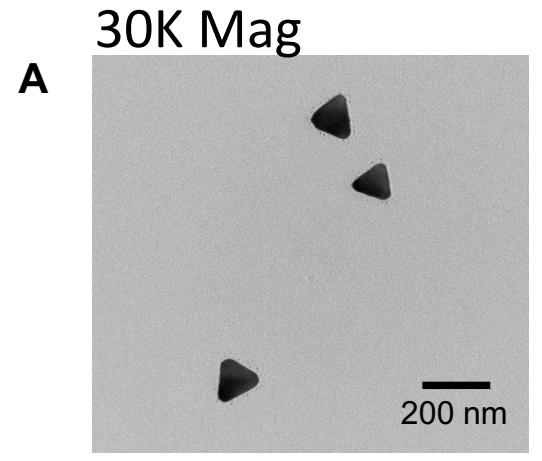

B

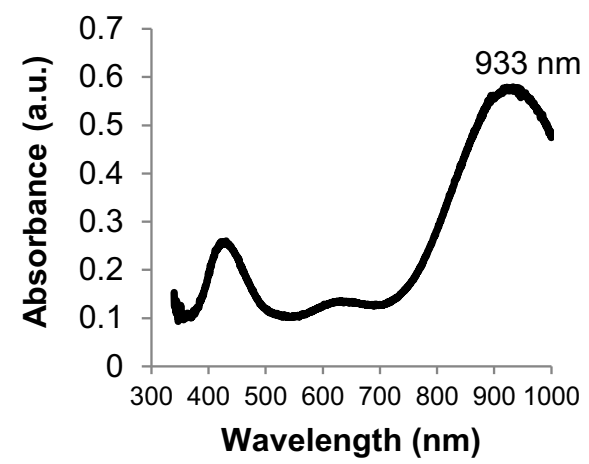

C

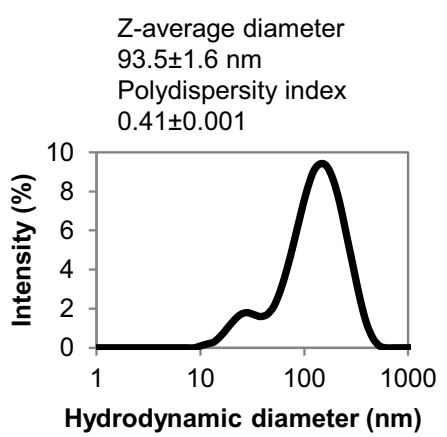

D

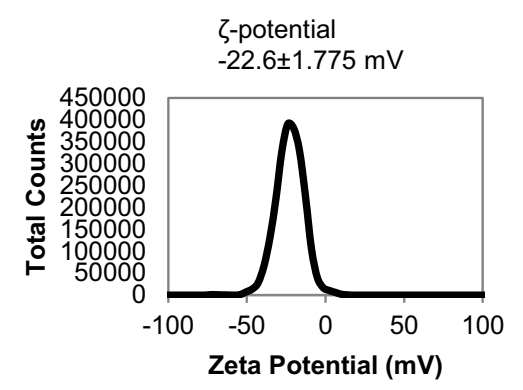

Figure I Physicochemical characteristics of TAgNPs were determined. (A) An electron micrograph shows the triangular structure of TAgNPs. (B) The UV-Vis spectrum of a $6.25 \mu \mathrm{g} / \mathrm{mL}$ TAgNPs in water is shown. (C) The hydrodynamic and (D) $\zeta$-potential of $6.25 \mu \mathrm{g} / \mathrm{mL}$ TAgNPs in water are shown. Data in c and d are representative of triplicate independent measurements, and mean values with standard deviations are displayed.

$12.5 \mu \mathrm{g} / \mathrm{mL}$, no significant decrease in viability was observed for TAgNP treated MCF-10A cells. Even at a dose of $50 \mu \mathrm{g} / \mathrm{mL}$, which caused viability of MDA-MB -231 cells to significantly decrease $(p<0.05)$ to $44 \%$, the viability of MCF-10A cells only decreased to $81 \%$ relative to untreated controls.

Based upon these data, we established that a TAgNP dose of less than $12.5 \mu \mathrm{g} / \mathrm{mL}$ offered the optimal balance between cytotoxicity toward MDA-MB-231 cells and lack of toxicity toward MCF-10A cells. When performing toxicity assays in plates with different sizes and different treatment volumes, concentration-based calculations can vary substantially from exposed dose. To enable direct comparison between the effects observed in each assay, TAgNPs were dosed by calculating mass per unit cell growth surface area to keep the exposed dose similar across various assays (Figure 2B). For example, a $10 \mu \mathrm{g} / \mathrm{mL}$ TAgNP concentration in a well of a 96-well plate yields an exposed dose of $6.25 \mu \mathrm{g} / \mathrm{cm}^{2}$ for the volume of media used in the MTT assay described above. A similar exposed dose of $6.36 \mu \mathrm{g} / \mathrm{cm}^{2}$ is achieved using a $25 \mu \mathrm{g} / \mathrm{mL}$ TAgNP concentration in a $100-\mathrm{mm}$ plate under the conditions used for the flow cytometry analysis of apoptosis described below.

To determine if TAgNPs were inducing apoptotic cell death, MCF-10A and MDA-MB-231 cells were treated with TAgNPs $\left(25 \mu \mathrm{g} / \mathrm{mL} ; 6.36 \mu \mathrm{g} / \mathrm{cm}^{2}\right)$ for 24 hours, co-stained with a fluorescent antibody for annexin $\mathrm{V}$ (AnnV) and propidium iodide (PI), and fluorescence was quantified by flow cytometry. When MDA-MB-231 cells were treated with TAgNPs, early-stage apoptosis $\left(\mathrm{AnnV}^{+} / \mathrm{PI}^{-}\right.$staining, lower right quadrant) increased from $0.28 \%$ to $8.55 \%$ (30fold), and late-stage apoptosis $\left(\mathrm{AnnV}^{+} / \mathrm{PI}^{+}\right.$staining, upper right quadrant) increased from $1.66 \%$ to $9.35 \%$ (5.6-fold) when compared to vehicle-treated control cells (Figure 2C). There was a slight increase in necrotic cells (AnnV ${ }^{-} / \mathrm{PI}^{+}$ staining, upper left quadrant) from $3.42 \%$ to $4.24 \%$ in TAgNP treated MDA-MB-231 cells. In contrast, MCF$10 \mathrm{~A}$ cells treated with equivalent doses of TAgNPs showed minimal changes in early-stage apoptosis, late-stage apoptosis, or necrosis compared to vehicle-treated control cells (Figure 2D). These data indicate that TAgNPs induce apoptosis in TNBCs leading to cell death, but do not affect the viability or induce apoptosis/necrosis in non-malignant breast cells treated with equivalent TAgNP doses. 


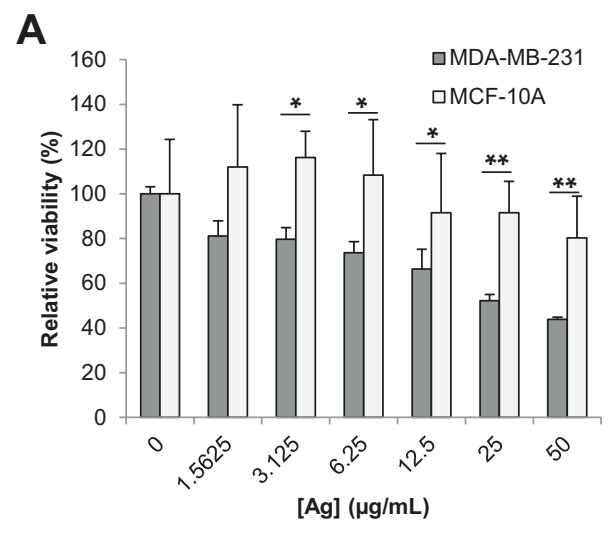

C

MDA-MB-231
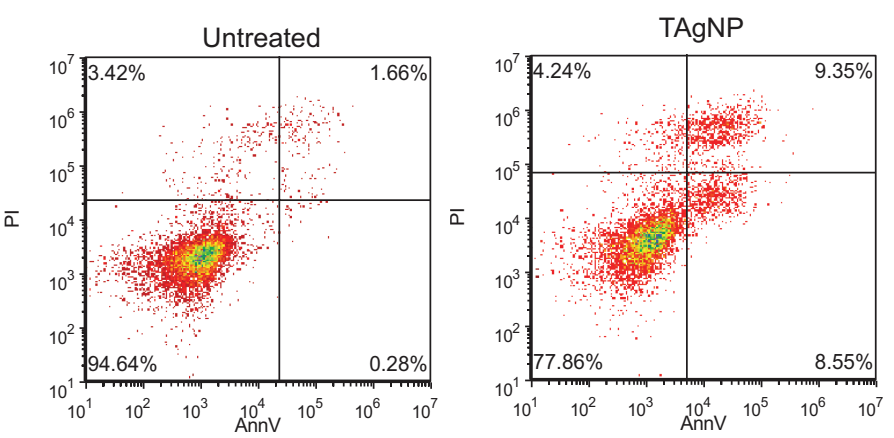

B

\begin{tabular}{|l|l|l|l|l|}
\hline Plate & $\begin{array}{l}\text { Cell } \\
\text { growth } \\
\text { surface } \\
\text { area } \\
\left(\mathbf{c m}^{2}\right)\end{array}$ & $\begin{array}{l}\text { TAgNP } \\
\text { concentration } \\
(\boldsymbol{\mu g} / \mathbf{m L})\end{array}$ & $\begin{array}{l}\text { Treatment } \\
\text { volume } \\
(\mathbf{m L})\end{array}$ & $\begin{array}{l}\text { TAgNP } \\
\text { exposed } \\
\text { dose } \\
\left(\boldsymbol{\mu g} / \mathbf{c m}^{2}\right)\end{array}$ \\
\hline 96 well & 0.32 & 10 & 0.2 & 6.25 \\
\hline 48 well & 0.95 & 12.5 & 0.5 & 6.57 \\
\hline $100 \mathrm{~mm}$ & 55 & 25 & 14 & 6.36 \\
\hline
\end{tabular}

D

$\underline{\text { MCF-10A }}$
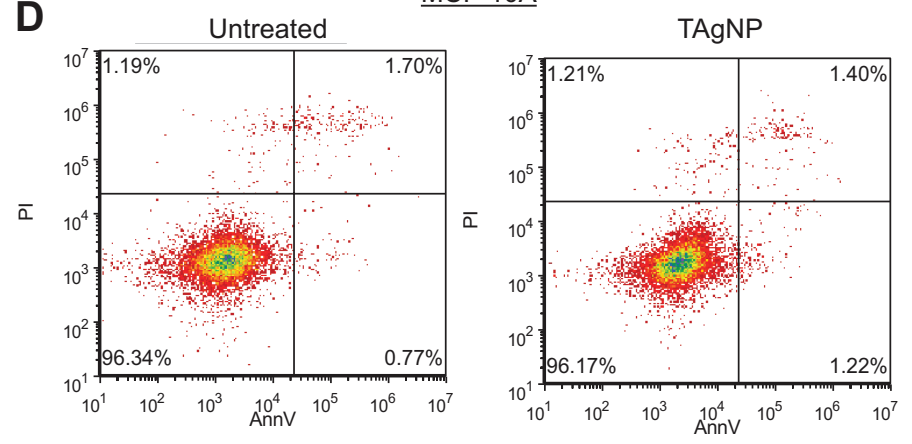

Figure 2 TAgNPs are more cytotoxic to TNBC than to non-malignant mammary epithelial cells. (A) Relative viability of MCF-10A and MDA-MB-23I after 72-hour treatment with TAgNPs $(0-50 \mu \mathrm{g} / \mathrm{mL})$. Viability was assessed by MTT assay. Data is representative of at least 3 independent experiments. Statistical analysis was performed by two-way ANOVA followed by post hoc Tukey's test. Statistical differences are indicated $\left({ }^{*}<<0.05 ; * *^{*}<0.01\right)$. (B) The dose per unit area in comparison to the concentration of TAgNPs was calculated for various well sizes and is shown in tabular form. (C) MDA-MB-23I and (D) MCF-IOA cells were treated with I2.5 $\mu$ g/mL TAgNPs for 24 hours. Cells were co-stained with propidium iodide (PI) and annexin V (AnnV), and then evaluated by flow cytometry. The percentages of cells characterized as viable (lower-left quadrant), early apoptotic (lower-right quadrant), late apoptotic (upper-right quadrant) and necrotic (upper-left quadrant) are shown with each quadrant. The presented data are representative of duplicate independent experiments.

\section{Cytotoxicity of TAgNPs in TNBC Cells is Enhanced by NIR Exposure}

We next assessed the photothermal heating characteristics of TAgNPs. Initially, we determined the effect on temperature change with increasing concentrations of TAgNPs exposed to a fixed laser energy ( $3 \mathrm{~W}$ for $60 \mathrm{~s}$ at a 970 $\mathrm{nm}$ wavelength). There was a significant increase in temperature $(\mathrm{P}<0.01)$ following TAgNP exposure compared to the vehicle control (Figure 3A). Next, we exposed a fixed concentration of TAgNPs $(12.5 \mu \mathrm{g} / \mathrm{mL} ; 6.57 \mu \mathrm{g} /$ $\mathrm{cm}^{2}$ ) to increased laser energy by varying the power from $1.5 \mathrm{~W}$ to $9.0 \mathrm{~W}$ for a fixed time $(60 \mathrm{~s})$. Likewise, the temperature of wells containing TAgNPs was significantly greater $(\mathrm{P}<0.01)$ for all conditions compared to wells without TAgNPs (Figure 3B). Lastly, we assessed the effect of increasing laser exposure time at a fixed power $(3 \mathrm{~W})$ on temperature change in wells containing 0 or 12.5 $\mu \mathrm{g} / \mathrm{mL}$ TAgNPs. Again, regardless of exposure time, the temperature rise was significantly greater $(\mathrm{P}<0.01)$ for wells containing TAgNPs compared to wells without TAgNPs (Figure 3C). Taken together, these data indicate that use of TAgNPs offers an advantage over laser irradiation alone for generation of heat over a wide range of TAgNP concentrations, laser powers, and laser exposure times.

We hypothesized that combination of TAgNP cytotoxicity and heating induced by NIR laser irradiation could cause cell death in TNBCs under conditions that did not affect non-malignant mammary epithelial cells. The cytotoxic effects of heat are dependent upon the temperature and the duration of exposure. If the temperature is sufficiently high, or duration sufficiently long, all cells will die, and it will not be possible to separate cytotoxic affects due to heating alone from those due to co-administration of TAgNPs. Therefore, it was necessary to define the optimal heating window for enhancement of photothermal treatment with co-administered TAgNPs. To do this, MDA-MB -231 and MCF-10A cells were exposed to of $0,6.25$, or $12.5 \mu \mathrm{g} / \mathrm{mL}$ (equivalent to $0,3.285$, or $6.57 \mu \mathrm{g} / \mathrm{cm}^{2}$, 
A

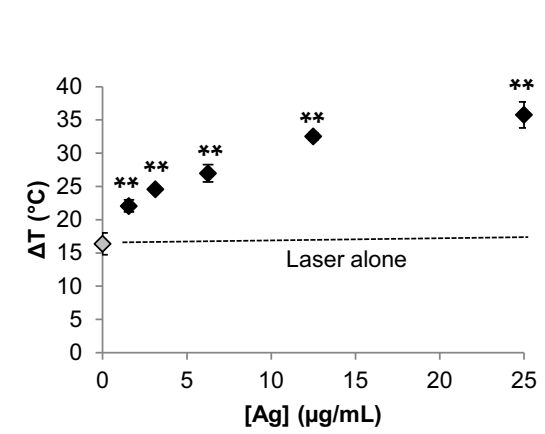

D

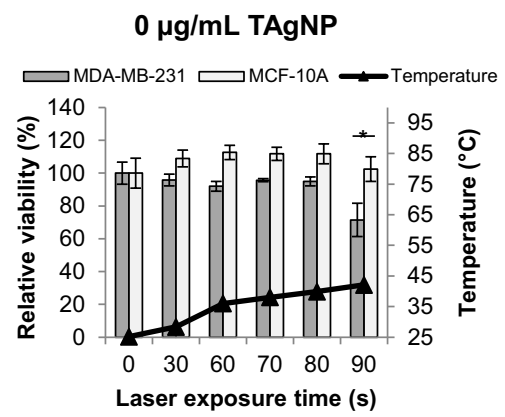

B

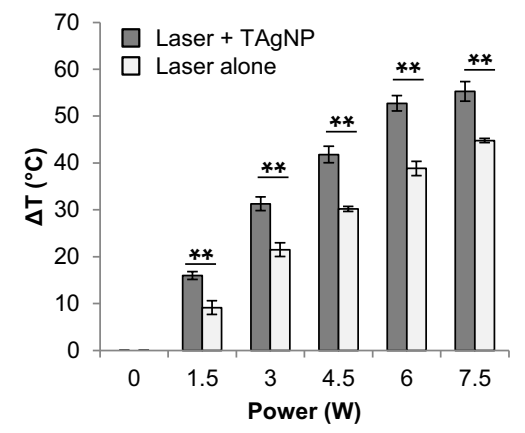

E
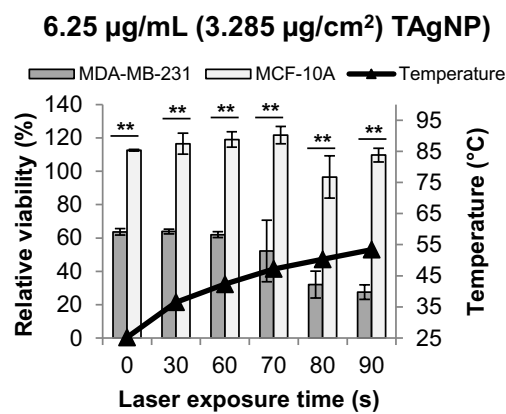

C

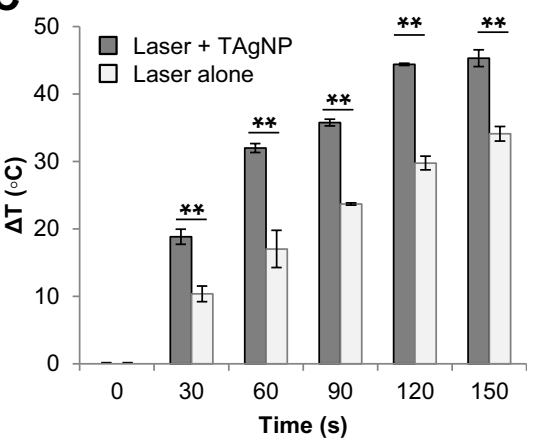

F

$\left.12.5 \mu \mathrm{g} / \mathrm{mL}\left(6.57 \mu \mathrm{g} / \mathrm{cm}^{2}\right) \mathrm{TAgNP}\right)$

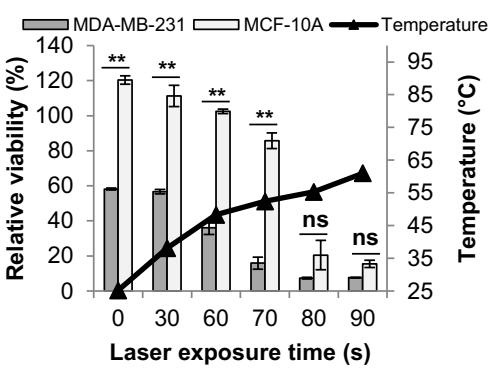

Figure 3 NIR radiation enhances TAgNP cytotoxicity in TNBC cells. (A) Cell culture media containing various concentrations of TAgNPs was exposed to NIR at a fixed power and duration ( $3 \mathrm{~W}$ for $60 \mathrm{~s}$ at a $950 \mathrm{~nm}$ wavelength) and change in temperature $(\Delta \mathrm{T}$ ) was assessed. (B) $12.5 \mu \mathrm{g} / \mathrm{mL} T \mathrm{TgNPs}$ were exposed to NIR at varying power (I.5 W to $9.0(\mathrm{~W})$ for 60 seconds and $\Delta \mathrm{T}$ was assessed. (C) Cell culture media containing a fixed concentration of TAgNPs (I2.5 $\mu \mathrm{g} / \mathrm{mL}$ ) was exposed to NIR for increasing durations at a fixed power ( 3 (W) and $\triangle T$ was assessed. (D-E) MCF-IOA and MDA-MB-23I cells were treated with TAgNPs and irradiated with a 3 W, $970 \mathrm{~nm}$ NIR laser for increasing amounts of time (0-90 s) and cell viability was assessed 72 hours later by MTT assay. MCF-I0A and MDA-MB-23I cells treated with $0 \mu \mathrm{g} / \mathrm{mL}$ (D), $6.25 \mu \mathrm{g} / \mathrm{mL}$ (E), or $12.5 \mu \mathrm{g} / \mathrm{mL}(\mathbf{F})$ doses of TAgNP and irradiated with an NIR laser. Temperature measurements shown in (D-F) were made in a separate set of wells under identical treatment, and the final temperatures achieved are shown. Values are reported as the mean \pm standard deviation of triplicate measurements relative to the untreated control for each cell line. Statistical analysis was performed by two-way ANOVA followed by post hoc Tukey's test. Significant differences are indicated $\left({ }^{*} p<0.05\right.$; $\left.* * p<0.01\right)$. ns: not significant. The presented data are representative of duplicate independent experiments.

respectively) of TAgNPs for $3 \mathrm{~h}$, and then heated using a 3 $\mathrm{W}, 970 \mathrm{~nm}$ NIR laser for increasing time. In the absence of TAgNPs, a maximum temperature of $44^{\circ} \mathrm{C}$ was reached after $90 \mathrm{~s}$ NIR exposure (Figure 3D). After treatment with $6.25 \mu \mathrm{g} / \mathrm{mL}\left(3.285 \mu \mathrm{g} / \mathrm{cm}^{2}\right)$ TAgNPs combined with NIR exposure for 80 or $90 \mathrm{~s}$, temperature rose to 50.3 or $53.4^{\circ} \mathrm{C}$ respectively, and the viability of MDA-MB-231 cells decreased to less than $30 \%$ compared to the untreated control (Figure 3E). Exposure of MCF-10A cells to the same dose of TAgNPs and NIR induced a slight, but nonsignificant, increase in MCF-10A proliferation compared to untreated controls (Figure 3E). Following treatment with a $12.5 \mu \mathrm{g} / \mathrm{mL}\left(6.57 \mu \mathrm{g} / \mathrm{cm}^{2}\right)$ TAgNP dose combined with NIR exposure for $70 \mathrm{~s}$, temperature reached $52.4^{\circ} \mathrm{C}$, and viability of MDA-MB-231 cells decreased to less than $15 \%$ compared to the untreated control (Figure 3F). In contrast, the viability of MCF-10A cells decreased to $85 \%$ of the untreated control under equivalent conditions. Treatment with a $12.5 \mu \mathrm{g} / \mathrm{mL}\left(6.57 \mu \mathrm{g} / \mathrm{cm}^{2}\right)$ TAgNP dose in combination with NIR exposure for 80-90 s was lethal to both cell lines due to thermal ablation (Figure 3F).

We noted that the rise in temperature of the media for cells treated with laser and TAgNP was less than predicted from cell-free experiments. For example, the $12.5 \mu \mathrm{g} / \mathrm{mL}$ TAgNP $\left(6.57 \mu \mathrm{g} / \mathrm{cm}^{2}\right)$ TAgNP dose combined with $3 \mathrm{~W}$, $60 \mathrm{~s}$ NIR exposure produced a temperature rise of $30-32^{\circ}$ $\mathrm{C}$ (Figure 3A-C). However, when cells were heated under similar conditions, the temperature rose from a baseline of $20.5^{\circ} \mathrm{C}$ to $48.3^{\circ} \mathrm{C}$, a change of only $27.8^{\circ} \mathrm{C}$. In contrast, temperature rise following exposure to NIR alone was in the range of $16-17^{\circ} \mathrm{C}$, both in the presence and absence of cells. This indicated that differences in TAgNP photothermal conversion efficiency, rather than a general effect on NIR absorbance, was the likely cause of the change in heating efficiency. Previous reports showed that etching of TAgNPs following cell uptake can affect their photothermal efficiency. ${ }^{46}$ Therefore, we examined the structure of TAgNPs following uptake using TEM (Figure 4A and B). 
After 3 hours, TAgNPs were observed in membrane-bound vesicles in both MDA-MB-231 and MCF-10A cells. In MDA-MB-231 cells, particles were degraded and were localized to late endosomes, multivesicular bodies (MVB), and amphisomes, which are formed by fusion of late endosomes/MVB and autophagosomes. In MCF-10A cells, TAgNPs appeared less degraded, but they had lost their triangular shape due to etching.

This data suggests that under sub-ablative conditions, the combination of the cytotoxic and heat-generating properties of TAgNPs following laser irradiation may be beneficial for the treatment of TNBC without having adverse effects on the surrounding normal breast epithelium. However, following uptake, TAgNPs begin etching and loose photothermal efficiency. It is likely extracellular TAgNPs, rather than internalized TAgNPs play a dominant role in heat generation following NIR irradiation.

\section{TAgNPs Sensitize TNBC Cells to lonizing Radiation Without Affecting the Radiosensitivity of Non-Tumorigenic Cells}

We next characterized the sensitivity of MDA-MB-231 and MCF-10A cells to combinations of TAgNP and IR

A

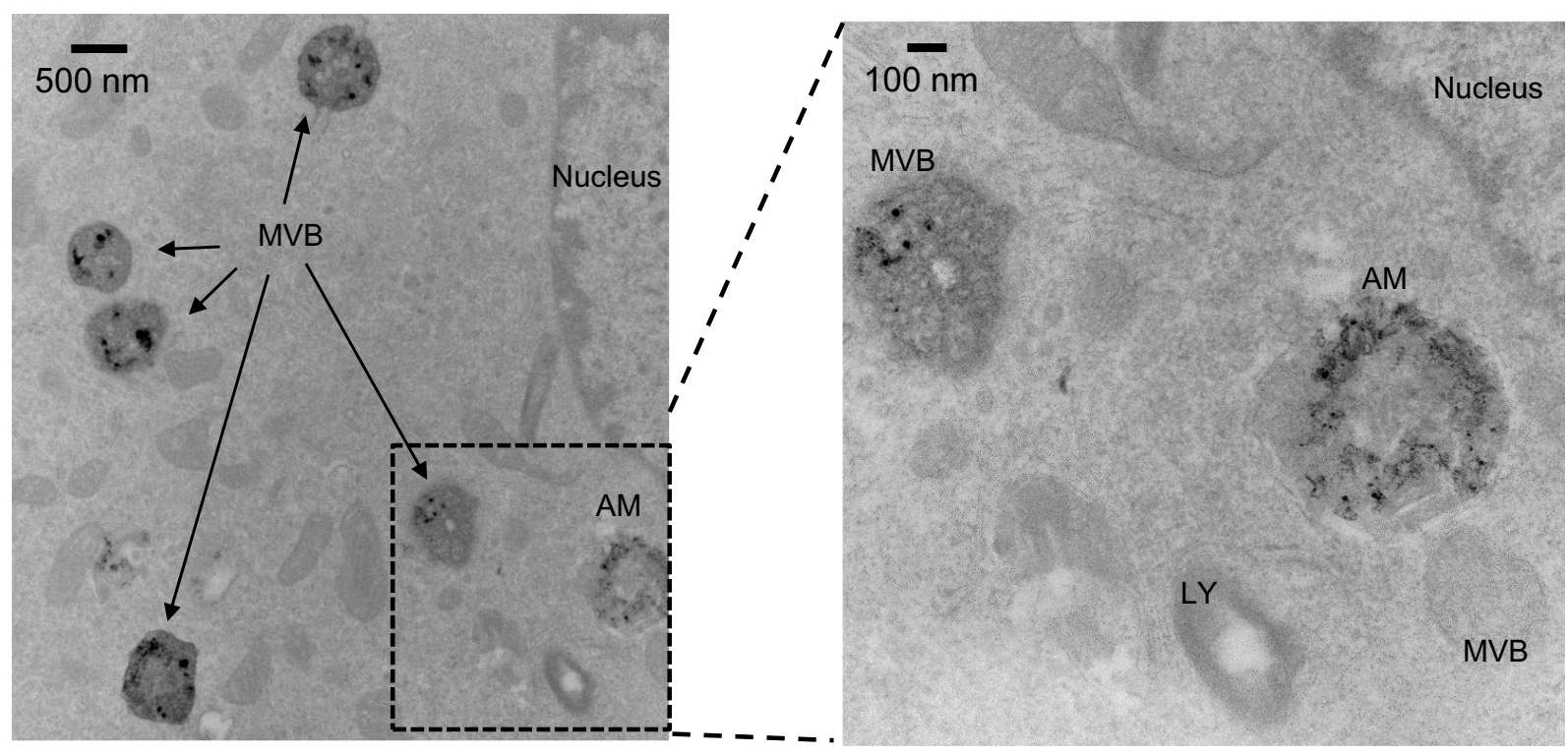

B

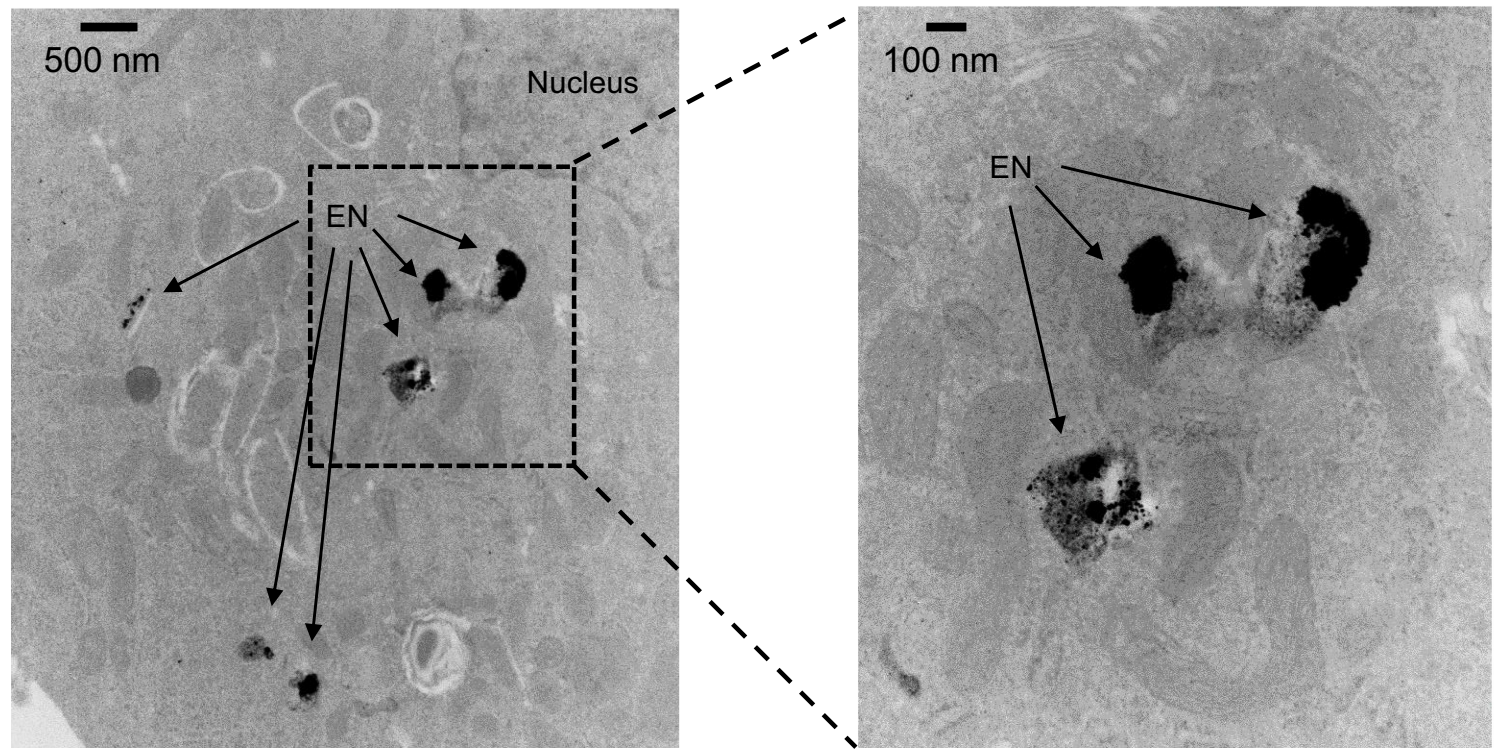

Figure 4 Uptake and trafficking of TAgNPs visualized by TEM. (A) Electron micrographs show degraded particles in multivesicular bodies and amphisomes in MDA-MB-23I cells after 3 hours at II000X magnification (left) or 30000X magnification (right). (B) Electron micrographs show degraded particles in endosomes in MCF-I0A cells after 3 hours at II000X magnification (left) or 30000X magnification (right). EN, endosome; AM, amphisome; LY, lysosome; MVB, multivesicular body. 
using clonogenic assays. Cells were plated at low density (300 cells/well), and treated the following day with either TAgNP, IR, TAgNP and IR, or vehicle. We found that TAgNP treatment alone significantly reduced clonogenic growth in MDA-MB-231 cells with minimal effect on MCF-10A cells for all doses evaluated (Figure 5A). Furthermore, both 1.25 and $2.5 \mu \mathrm{g} / \mathrm{mL}$ doses of TAgNPs sensitized MDA-MB-231 cells to IR (Figure 5B). The combination index (CI) of IR and TAgNPs treatment was determined by dividing the surviving fraction of cells treated with IR alone (normalized to untreated cells) by the surviving fraction of cells treated of cells treated with IR in combination with TAgNPs (normalized to cells treated with an equivalent dose of TAgNPs alone). If the $\mathrm{CI}$ is $<1$, the combination is antagonistic. For $\mathrm{CI}=1$, the combination was additive, and for $\mathrm{CI}>1$ the
A

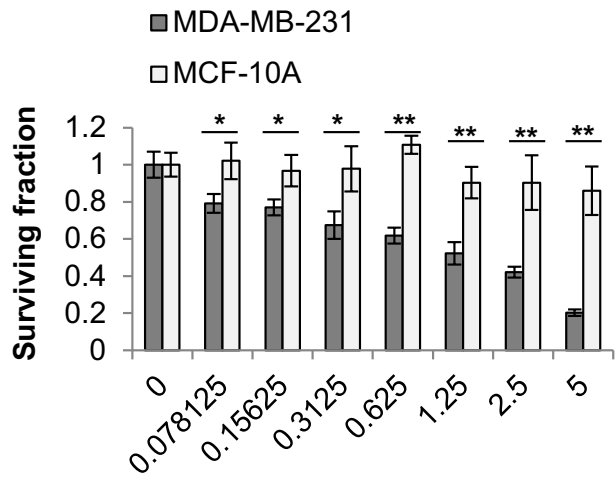

[Ag] $(\mu \mathrm{g} / \mathrm{mL})$
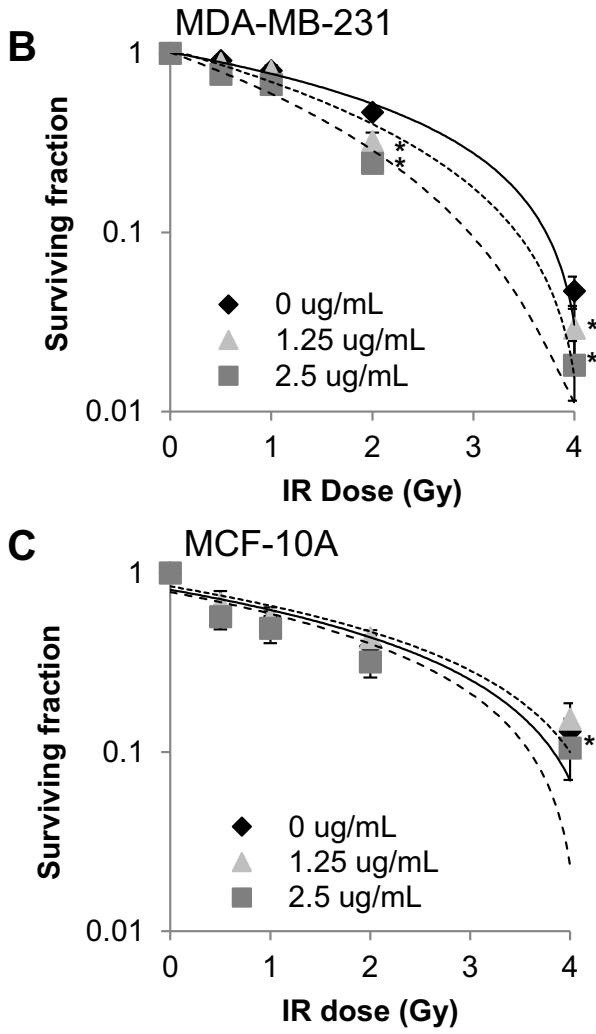

\begin{tabular}{|l|l|l|l|l|}
\cline { 2 - 5 } $\begin{array}{l}\text { MDA-MB- } \\
\mathbf{2 3 1}\end{array}$ & $\mathbf{0 . 5}$ Gy & $\mathbf{1 ~ G y}$ & $\mathbf{2} \mathbf{G y}$ & $\mathbf{4} \mathbf{G y}$ \\
\hline $\begin{array}{l}\mathbf{1 . 2 5} \mathbf{\mu g} / \mathbf{m l} \\
\text { TAgNP }\end{array}$ & $1.04 \pm 0.11$ & $1.01 \pm 0,01$ & $1.45 \pm 0.06$ & $1.61 \pm 0.02$ \\
\hline $\begin{array}{l}\mathbf{2 . 5} \mathbf{~} \mathbf{g} / \mathbf{m l} \\
\text { TAgNP }\end{array}$ & $1.19 \pm 0.1$ & $1.19 \pm 0.13$ & $1.93 \pm 0.03$ & $2.6 \pm 0.02$ \\
\hline
\end{tabular}

\begin{tabular}{|l|l|l|l|l|}
\cline { 2 - 5 } \multicolumn{1}{c|}{$M C F-10 A$} & $\mathbf{0 . 5}$ Gy & 1 Gy & $\mathbf{2 ~ G y ~}$ & $\mathbf{4}$ Gy \\
\hline $\begin{array}{l}\mathbf{1 . 2 5} \boldsymbol{\mu g} / \mathrm{ml} \\
\text { TAgNP }\end{array}$ & $0.88 \pm 0.18$ & $0.96 \pm 0.17$ & $0.88 \pm 0.10$ & $0.87 \pm 0.06$ \\
\hline $\begin{array}{l}\mathbf{2 . 5} \boldsymbol{\mu g} / \mathrm{ml} \\
\text { TAgNP }\end{array}$ & $1.05 \pm 0.15$ & $1.1 \pm 0.16$ & $1.22 \pm 0.12$ & $1.30 \pm 0.02$ \\
\hline
\end{tabular}

Figure 5 IR enhances TAgNP cytotoxicity in TNBC. (A) Long-term proliferative potential was assessed via clonogenic assay in MDA-MB-23I and MCF-I0A cell lines following TAgNP treatment $(0-5 \mu \mathrm{g} / \mathrm{mL})$. (B, C) Long-term proliferative potential was assessed via clonogenic assay with increasing doses of IR (0-4 Gy) following 24 $\mathrm{h}$ TAgNP treatment in (B) MDA-MB-23I and (C) MCF-IOA cells. The combination index (CI) of IR and TAgNPs treatment of each cell line are shown in the tables on the right. The data are presented as the surviving fraction of cells based upon clonogenic growth normalized to the plating efficiency of cells exposed to the relevant dose of $\mathrm{AgNPs}$ in the absence of ionizing radiation. Values are reported as the mean \pm standard deviation of triplicate measurements relative to the untreated control for each cell line. Statistical analysis was performed using two-way ANOVA followed post hoc Tukey's test. Significant differences are indicated $(* \mathrm{p}<0.05 ; * * p<0.0 \mathrm{I})$. The presented data are representative of duplicate independent experiments. 
combination was super-additive or synergistic. The CIs for treatment of MDA-MB-231 cells with 1.25 and 2.5 $\mu \mathrm{g} / \mathrm{mL}$ doses of TAgNPs combined with 2 or 4 Gy IR were 1.93 and 2.6, respectively, indicating that the combination was twice or more as effective as what would be predicted based upon additive effects. In contrast, there was no observed dose enhancement when MCF-10A cells were treated with IR and TAgNP, except at the highest dose $(2.5 \mu \mathrm{g} / \mathrm{mL}$ TAgNP with 4 Gy IR) for which there was a modest increase in the CI (Figure 5C). These data demonstrate that low doses of TAgNPs can selectively sensitize TNBCs to IR with minimal effect on nonmalignant breast epithelial cells.

\section{TAgNP-Mediated Multimodal Therapy Reduces the Viability of TNBC}

Lastly, we evaluated the combined effects of TAgNPmediated photothermal therapy and radiosensitization. To assess the multimodal potential of TAgNPs treatment, MDA-MB-231 and MCF-10A cell lines were exposed to a combination of $12.5 \mu \mathrm{g} / \mathrm{mL}\left(6.57 \mu \mathrm{g} / \mathrm{cm}^{2}\right)$ TAgNPs and $60 \mathrm{~s}$ laser exposure, followed immediately by 2 Gy IR. At this dose of TAgNPs and NIR, the temperature rose to 48.3 $\pm 0.57^{\circ} \mathrm{C}$, resulting in a small decrease in viability of MDA-MB-231 cells relative to TAgNP treatment alone as shown in Figure 3F. However, this same treatment did not affect MCF-10A cells, and thus offered the opportunity to see if the selectivity of TAgNP-mediated photothermal therapy for TNBC cells could be increased by IR without off-target effects. We found that treatment of MDA-MB -231 cells with the triple combination was more effective than any individual treatment or combination of two treatments, reducing viability to less than $30 \%$ compared to untreated controls (Figure 6A). In contrast, the viability of MCF-10A cells was reduced to $87 \%$ of untreated controls, primarily due to IR (Figure 6B). These studies offer proof of concept evidence that a combination therapy utilizing the cytotoxicity of TAgNPs, photothermal therapy, and IR is more effective than the individual components for selective treatment of TNBC cells, while inducing minimal offtarget effects.

\section{Discussion}

Radiation sensitizers, including high $\mathrm{Z}$ nanomaterials, ${ }^{21-29,47}$ have the potential to play crucial roles in decreasing off-target IR-induced toxicity. Heat is also a potent dose enhancer to the effects of IR. ${ }^{39-41}$
Therefore, we sought to develop a selective strategy for thermoradiation sensitization of cancer cells using nanomaterials. In previous studies, we found that TNBCs were more sensitive to AgNP-induced cytotoxicity, ${ }^{32}$ radiation sensitization, ${ }^{23}$ and photothermal therapy ${ }^{38}$ than nonmalignant breast epithelial cells. Here, we determined the effect of combining each of these modalities in a single therapy. We found that TAgNP-mediated photothermal therapy and radiosensitization offer a high degree of specificity for treatment of TNBC without affecting nonmalignant mammary epithelial cells.

Previously, Atkinson et al demonstrated that gold nanoparticle (AuNP)-mediated photothermal therapy sensitized breast cancer cells and tumors to IR. ${ }^{26}$ Similarly, Hainfeld and colleagues, who pioneered radiation sensitization using AuNPs, ${ }^{24}$ also demonstrated dramatic thermoradiosensitization of mouse melanoma tumors using AuNPs. ${ }^{25}$ However, the selectivity of these treatments requires confining the AuNPs, heat, and radiation only to the tumor cells because both normal and cancer cells in the treatment field will be affected equally. Effective treatment at invasive tumor margins may result in considerable damage to normal breast tissue using these previous approaches. Our data indicate there is a therapeutic window in which TAgNPs, IR, and heat combine to kill TNBC cells, but equivalent treatment has a minimal effect on nonmalignant mammary epithelial cells. The combined effects of thermoradiation sensitization using TAgNPs may be particularly useful for treating tumor margins, which might be exposed to sublethal doses of TAgNPs, heat, or IR if used individually due to limits on drug delivery, thermal diffusion, and the need to spare normal tissue from IR exposure.

We observed that TAgNPs sensitized MDA-MB-231 cells to IR at doses that did not sensitize MCF-10A cells, which is in agreement with our previous studies using spherical AgNPs. ${ }^{23}$ Liu et al showed improved radiation sensitization with AgNPs compared to AuNPs in glioblastoma. ${ }^{21}$ This indicates that in the right biological context, AgNPs may offer advantages over AuNPs as radiation sensitizers. Silver-based nanotherapeutics generate reactive oxygen species, deplete antioxidants such as glutathione, ${ }^{48}$ increase protein oxidation, ${ }^{23,47,49}$ and cause endoplasmic reticulum stress. ${ }^{33,50,51}$ It is likely that these stresses contribute to TNBC specific, AgNP-induced radiothermosensitization. Based upon our previous studies, the threshold for induction of these forms of damage differs between TNBC cells and models of normal breast 
A

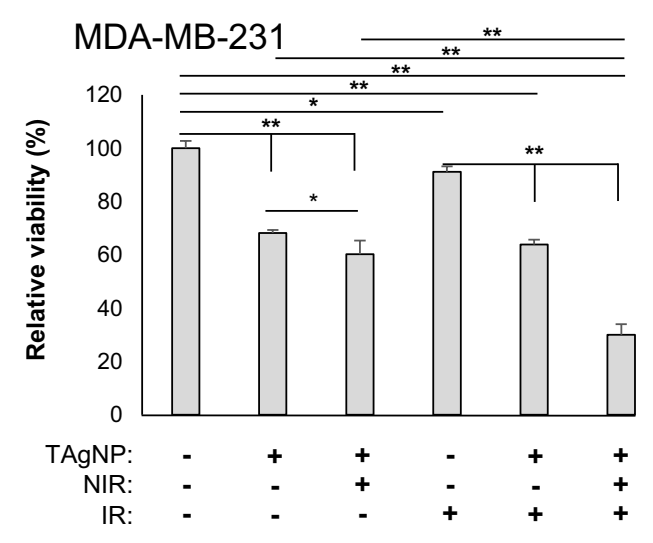

B

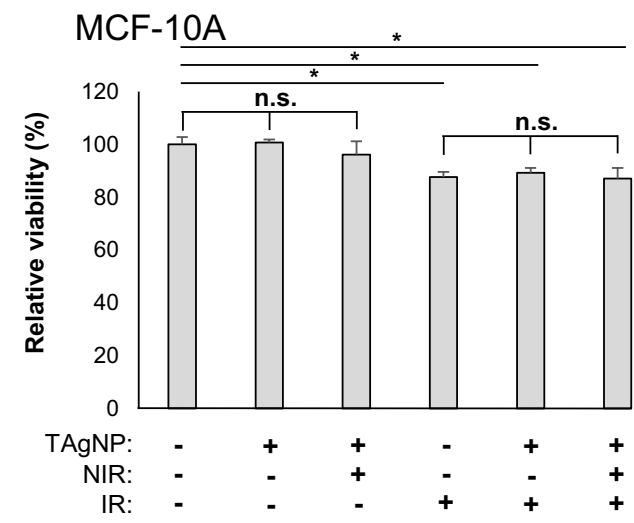

C

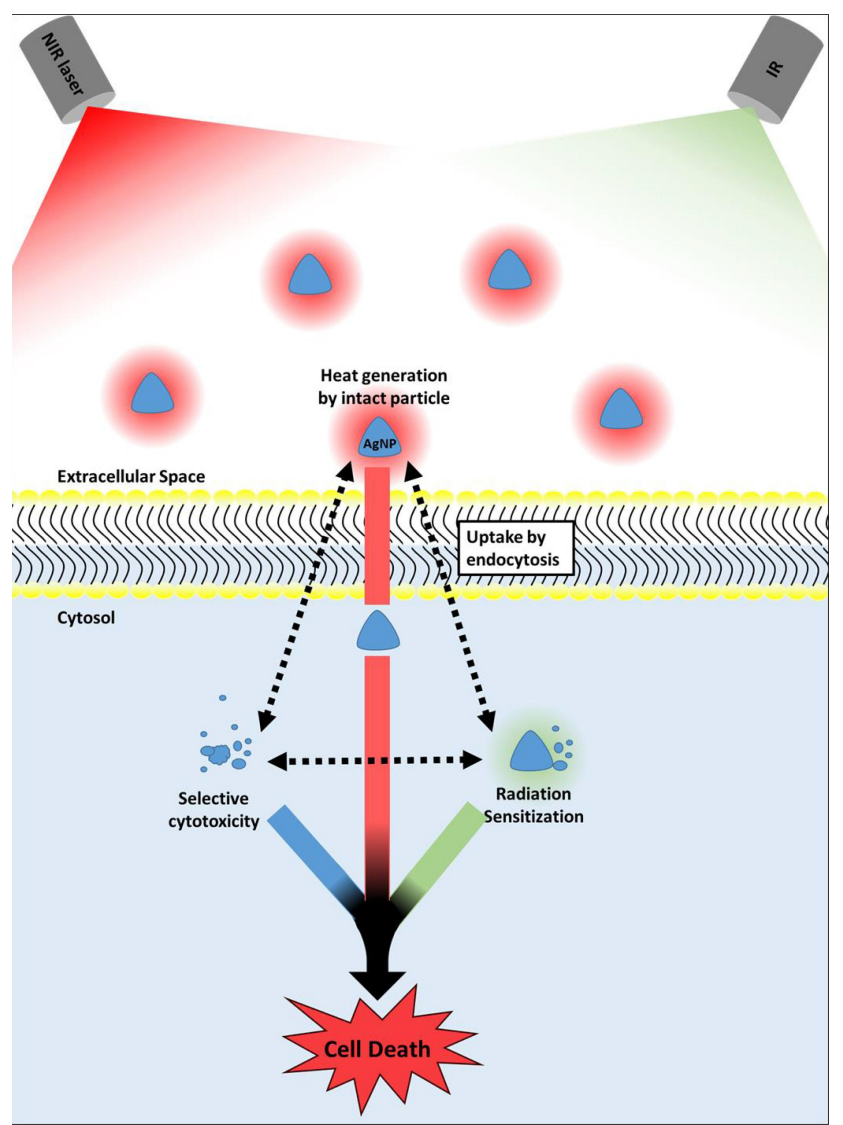

Figure 6 TAgNP-based trimodal treatment is highly cytotoxic to TNBC cells. MDA-MB-23I (A) and MCF-10A (B) cells were treated with $10 \mu \mathrm{gg} / \mathrm{mL}$ TAgNPs for 3 hours followed by exposure to NIR laser for $60 \mathrm{~s}$ and IR (0-2 Gy). Cells were then allowed to incubate with TAgNPs for 72 hours. After 72 hours, cell viability was assessed by MTT assay. Each condition was normalized to the untreated control for each cell line and is reported as the mean of six replicates \pm standard deviation. Results are representative of two independent experiments. Statistical analysis was performed by two-way ANOVA followed by post hoc Tukey's test. Significant differences are indicated $\left({ }^{*}<0.05 ;{ }^{*} \mathrm{p}<0.01\right)$. The presented data are representative of duplicate independent experiments. (C) A schematic representation of thermoradiosensitization using TAgNPs is shown. Intact nanoparticles in the extracellular space generate heat when exposed to a NIR laser. A portion of TAgNPs are taken up by cells and are partially degraded. Internalized TagNPs are cytotoxic to TNBC cells and act as IR and thermal sensitizers. Hyperthermia also sensitizes the cells to IR. Under optimal conditions, these three modalities combine to selectively induce TNBC cell death, while having little effect on non-malignant mammary epithelial cells.

epithelium, but the difference in sensitivity is not due to increased uptake of AgNPs by TNBC cells, nor due to inherent sensitivity of TNBC cells to silver ion. ${ }^{32}$ More research is needed to determine the biological factors responsible for the sensitivity of TNBC cells to AgNPs.

When exposed to a NIR laser, TAgNPs generate heat, which further sensitizes TNBC cells to IR and increases the cytotoxic effects on TNBC cells without affecting the viability of non-malignant breast cells. Hyperthermia also can impair DNA damage signaling and repair pathways. $^{52,53}$ Both IR and AgNPs induce DNA damage, and the combination of spherical AgNPs and IR additively increases indicators of DNA double-strand breaks. ${ }^{23}$ Furthermore, we previously observed that spherical AgNPs can specifically induce DNA damage in MDAMB-231 cells at doses that do not cause DNA damage in normal mammary epithelial cells. ${ }^{32}$ Inhibition of protective responses to DNA damage due to hyperthermia may enhance the selectivity of TAgNP thermoradiosensitization, but this will require further investigation to verify.

In agreement with previous studies, ${ }^{46}$ TAgNPs are degraded following uptake in TNBC cells. This reduces AgNP-mediated heat generation following laser irradiation. Stabilization of internalized TAgNPs to retain photothermal heat transduction efficiency at NIR wavelengths has been demonstrated by coating the surface with gold. ${ }^{46}$ Furthermore, graphene decorated TAgNPs also resist degradation following cell uptake and were shown to be effective radiation sensitizers. ${ }^{22}$ Whether other types of TAgNPs with greater stability offer an advantage over those used in this study remains to be determined. Under conditions typically used for photothermal therapy, the combined bulk heating of nanoparticles dispersed across the tumor volume, including those in the extracellular space, produces a global 
temperature rise orders of magnitude larger than the localized temperature rise near each particle. ${ }^{37,54}$ Thus, extracellular TAgNPs, which have not yet degraded will contribute to the overall heating. Internalized AgNPs will break down to induce cytotoxic effects by silver ion release and act as radiosensitizers to generate secondary electrons following IR exposure. The proposed mechanism of action is shown schematically in Figure 6C.

In summary, we combined TAgNP-mediated photothermal therapy, radiosensitization, and TNBC specific cytotoxicity into a single, multimodal treatment. We demonstrated that this combination is highly selective for TNBC cells but spares non-malignant mammary epithelial cells. This finding provides proof of principle evidence that TAgNP-based thermoradiation sensitization has the potential to reduce both the dose and frequency of IR treatment while yielding superior results in current regimens. This treatment would be particularly important for patients undergoing breast conservation therapy, and for the treatment of invasive tumor margins near the periphery where each individual treatment might be at a subtherapeutic level. However, there is a substantial gap between the studies performed in cancer cell lines and clinical translation, and this will require further investigation to bridge.

\section{Abbreviations}

AgNP, silver nanoparticle; AnnV, annexin V; CI, combination index; DLS, dynamic light scattering; ER, endoplasmic reticulum; IR, ionizing radiation; MTT, 3-[4,5-dimethylthiazol-2-yl]-2,5 diphenyl tetrazolium bromide; MVB, multivesicular body; NIR, near-infrared radiation; PBS, phosphate-buffered saline; PI, propidium iodide; TAgNP, triangular silver nanoparticle; TNBC, triple-negative breast cancer; $\mathrm{Z}$, atomic number.

\section{Consent for Publication}

All authors have agreed to publication of this manuscript in this journal.

\section{Acknowledgments}

We thank K Grant and P Graham for assistance in sample preparation for TEM, Y Karpova for establishing cell lines and performing mycoplasma tests, and J Strupe for performing mycoplasma tests.

\section{Author Contributions}

All authors made substantial contributions to conception and design, acquisition of data, or analysis and interpretation of data; took part in drafting the article or revising it critically for important intellectual content; agreed to submit to the current journal; gave final approval of the version to be published; and agree to be accountable for all aspects of the work.

\section{Funding}

Research in this work was supported by NIH/NCI R01CA207222 and a Sigma Xi grant in aid of research. Support for pre/post-doctoral training was provided in part by NIH/NIGMS T32GM127261 and NIH/NCI T32CA079448. Assistance provided by the Wake Forest University Comprehensive Cancer Center (WFUCCC) Cell Engineering Shared Resource, the Cellular Imaging Shared Resource, and the Flow Cytometry Shared Resource was supported in part by NIH/NCI CCSG P30CA012197. The content is solely the responsibility of the authors and does not necessarily represent the official views of the NIH or Sigma Xi.

\section{Disclosure}

The authors report no financial or other conflict of interests related to this work.

\section{References}

1. Cleator S, Heller W, Coombes RC. Triple-negative breast cancer: therapeutic options. Lancet Oncol. 2007;8(3):235-244. doi:10.1016/ S1470-2045(07)70074-8

2. Dent R, Trudeau M, Pritchard KI, et al. Triple-negative breast cancer: clinical features and patterns of recurrence. Clin Cancer Res. 2007;13 (15):4429-4434. doi:10.1158/1078-0432.CCR-06-3045

3. Panoff JE, Hurley J, Takita C, et al. Risk of locoregional recurrence by receptor status in breast cancer patients receiving modern systemic therapy and post-mastectomy radiation. Breast Cancer Res Tr. 2011;128(3):899-906. doi:10.1007/s10549-011-1495-1

4. Gong Y, Liu Y-R, Ji P, Hu X, Shao Z-M. Impact of molecular subtypes on metastatic breast cancer patients: a SEER population-based study. Scientific Rep. 2017;7(1):45411. doi:10.1038/srep45411

5. Holleczek B, Stegmaier C, Radosa JC, Solomayer E-F, Brenner H. Risk of loco-regional recurrence and distant metastases of patients with invasive breast cancer up to ten years after diagnosis - results from a registry-based study from Germany. Bmc Cancer. 2019;19 (1):520. doi:10.1186/s12885-019-5710-5

6. Rapiti E, Pinaud K, Chappuis PO, et al. Opportunities for improving triple-negative breast cancer outcomes: results of a population-based study. Cancer Med. 2017;6(3):526-536.

7. Steward LT, Gao F, Taylor MA, Margenthaler JA. Impact of radiation therapy on survival in patients with triple-negative breast cancer. Oncol Lett. 2014;7(2):548-552.

8. Abdulkarim BS, Cuartero J, Hanson J, Deschenes J, Lesniak D, Sabri S. Increased Risk of Locoregional Recurrence for Women With T1-2N0 Triple-Negative Breast Cancer Treated With Modified Radical Mastectomy Without Adjuvant Radiation Therapy Compared With Breast-Conserving Therapy. J Clin Oncol. 2011;29(21):2852-2858.

9. Haffty BG, Yang QF, Reiss M, et al. Locoregional relapse and distant metastasis in conservatively managed triple negative early-stage breast cancer. J Clin Oncol. 2006;24(36):5652-5657. 
10. Wang JH, Shi M, Ling R, et al. Adjuvant chemotherapy and radiotherapy in triple-negative breast carcinoma: A prospective randomized controlled multi-center trial. Radiother Oncol. 2011;100 (2):200-204. doi:10.1016/j.radonc.2011.07.007

11. Dragun AE, Pan JM, Rai SN, Kruse B, Jain D. Locoregional Recurrence in Patients With Triple-Negative Breast Cancer Preliminary Results of a Single Institution Study. Am J Clin Oncol. 2011;34(3):231-237. doi:10.1097/COC.0b013e3181dea993

12. Rice SR, Feigenberg SJ, Hamza M, et al. Trends in utilization of hypofractionated whole breast irradiation (HF-WBI) in triple negative breast cancer (TNBC): a national cancer database (NCDB) analysis. Breast Cancer Res Tr. 2019;175(2):473-478. doi:10.1007/ s10549-019-05150-x

13. Rippy EE, Ainsworth R, Sathananthan D, Kollias J, Bochner M, Whitfield R. Influences on decision for mastectomy in patients eligible for breast conserving surgery. Breast. 2014;23(3):273-278. doi:10.1016/j.breast.2013.12.009

14. Lam J, Cook T, Foster S, Poon R, Milross C, Sundaresan P. Examining Determinants of Radiotherapy Access: do Cost and Radiotherapy Inconvenience Affect Uptake of Breast-conserving Treatment for Early Breast Cancer? Clin Oncol. 2015;27 (8):465-471. doi:10.1016/j.clon.2015.04.034

15. Darby SC, Ewertz M, McGale P, et al. Risk of ischemic heart disease in women after radiotherapy for breast cancer. $N$ Eng $J$ Med. 2013;368(11):987-998. doi:10.1056/NEJMoa1209825

16. Back M. Impact of radiation therapy on acute toxicity in breast conservation therapy for early breast cancer. Clin Oncol. 2004;16 (1):12-16. doi:10.1016/j.clon.2003.08.005

17. White J, Joiner MC. Toxicity from radiation in breast cancer. Cancer Treat Res. 2006;128:65-109.

18. Brownlee Z, Garg R, Listo M, Zavitsanos P, Wazer DE, Huber KE. Late complications of radiation therapy for breast cancer: evolution in techniques and risk over time. Gland Surgery. 2018;7(4):371-378. doi:10.21037/gs.2018.01.05

19. Poortmans PM, Collette L, Horiot J-C, et al. Impact of the boost dose of $10 \mathrm{~Gy}$ versus $26 \mathrm{~Gy}$ in patients with early stage breast cancer after a microscopically incomplete lumpectomy: 10-year results of the randomised EORTC boost trial. Radiother Oncol. 2009;90 (1):80-85. doi:10.1016/j.radonc.2008.07.011

20. Vicini FA, Cecchini RS, White JR, et al. Long-term primary results of accelerated partial breast irradiation after breast-conserving surgery for early-stage breast cancer: a randomised, Phase 3, equivalence trial. Lancet. 2019;394(10215):2155-2164. doi:10.1016/S0140-6736(19)32514-0

21. Liu P, Jin H, Guo Z, et al. Silver nanoparticles outperform gold nanoparticles in radiosensitizing U251 cells in vitro and in an intracranial mouse model of glioma. Int J Nanomed. 2016;11:5003-5014. doi:10.2147/IJN.S115473

22. Habiba K, Aziz K, Sanders K, et al. Enhancing Colorectal Cancer Radiation Therapy Efficacy using Silver Nanoprisms Decorated with Graphene as Radiosensitizers. Scientific Rep. 2019;9(1):17120. doi:10.1038/s41598-019-53706-0

23. Swanner J, Mims J, Carroll DL, et al. Differential cytotoxic and radiosensitizing effects of silver nanoparticles on triple-negative breast cancer and non-triple-negative breast cells.. Int J Nanomedicine. 2015;10:3937-3953. doi:10.2147/IJN.S80349

24. Hainfeld JF, Dilmanian FA, Zhong Z, Slatkin DN, Kalef-Ezra JA, Smilowitz HM. Gold nanoparticles enhance the radiation therapy of a murine squamous cell carcinoma. Phys Med Biol. 2010;55 (11):3045-3059. doi:10.1088/0031-9155/55/11/004

25. Hainfeld JF, Lin L, Slatkin DN, Dilmanian FA, Vadas TM, Smilowitz HM. Gold nanoparticle hyperthermia reduces radiotherapy dose. Nanomedicine. 2014;10(8):1609-1617. doi:10.1016/j.nano.2014.05.006

26. Atkinson RL, Zhang M, Diagaradjane P, et al. Thermal Enhancement with Optically Activated Gold Nanoshells Sensitizes Breast Cancer Stem Cells to Radiation Therapy. Sci Transl Med. 2010;2(55):55ra79. doi:10.1126/scitranslmed.3001447
27. Wolfe T, Chatterjee D, Lee J, et al. Targeted gold nanoparticles enhance sensitization of prostate tumors to megavoltage radiation therapy in vivo. Nanomedicine. 2015;11(5):1277-1283. doi:10.10 16/j.nano.2014.12.016

28. Verry C, Sancey L, Dufort S, et al. Treatment of multiple brain metastases using gadolinium nanoparticles and radiotherapy: NANO-RAD, a Phase I study protocol. BMJ Open. 2019;9(2): e023591. doi:10.1136/bmjopen-2018-023591

29. Bonvalot S, Rutkowski PL, Thariat J, et al. NBTXR3, a first-in-class radioenhancer hafnium oxide nanoparticle, plus radiotherapy versus radiotherapy alone in patients with locally advanced soft-tissue sarcoma (Act.In.Sarc): a multicentre, Phase 2-3, randomised, controlled trial. Lancet Oncol. 2019;20(8):1148-1159. doi:10.1016/S14702045(19)30326-2

30. Pottier A, Borghi E, Levy L. The future of nanosized radiation enhancers. Br J Radiol. 2015;88(1054):20150171. doi:10.1259/ bjr.20150171

31. Howard D, Sebastian S, Le QV-C, Thierry B, Kempson I. Chemical Mechanisms of Nanoparticle Radiosensitization and Radioprotection: A Review of Structure-Function Relationships Influencing Reactive Oxygen Species. Int J Mol Sci. 2020;21(2):579. doi:10.3390/ijms 21020579

32. Swanner J, Fahrenholtz CD, Tenvooren I, et al. Silver nanoparticles selectively treat triple-negative breast cancer cells without affecting non-malignant breast epithelial cells in vitro and in vivo. FASEB Bioadvances. 2019;1(10):639-660. doi:10.1096/ fba.2019-00021

33. Simard J-C, Durocher I, Girard D. Silver nanoparticles induce irremediable endoplasmic reticulum stress leading to unfolded protein response dependent apoptosis in breast cancer cells. Apoptosis. 2016;21(11):1279-1290. doi:10.1007/s10495-016-1285-7

34. Cherukuri P, Glazer ES, Curleya SA. Targeted hyperthermia using metal nanoparticles. Adv Drug Delivery Reviews. 2010;62(3):3 39-345. doi:10.1016/j.addr.2009.11.006

35. Bashkatov AN, Genina EA, Kochubey VI, Tuchin VV. Optical properties of human skin, subcutaneous and mucous tissues in the wavelength range from 400 to $2000 \mathrm{~nm}$. J Phys D: Appl Phys. 2005;38 (15):2543. doi:10.1088/0022-3727/38/15/004

36. Nioka S, Chance B. NIR spectroscopic detection of breast cancer. Technol Cancer Res Treat. 2005;4(5):497-512. doi:10.1177/ 153303460500400504

37. Xie B, Singh R, Torti FM, Keblinski P, Torti S. Heat localization for targeted tumor treatment with nanoscale near-infrared radiation absorbers. Phys Med Biol. 2012;57(18):5765-5775. doi:10.1088/ 0031-9155/57/18/5765

38. Thompson EA, Graham E, MacNeill CM, et al. Differential response of MCF7, MDA-MB-231, and MCF 10A cells to hyperthermia, silver nanoparticles and silver nanoparticle-induced photothermal therapy. Int $J$ Hyperthermia. 2014;30(5):312-323. doi:10.3109/02656736. 2014.936051

39. Vernon I, Vernon C, Hand J, et al. Radiotherapy with or without hyperthermia in the treatment of superficial localized breast cancer: results from five randomized controlled trials. Int $J$ Radiat Oncol. 1996;35(4):731-744. doi:10.1016/0360-3016(96)00154-X

40. Wust P, Hildebrandt B, Sreenivasa G, et al. Hyperthermia in combined treatment of cancer. Lancet Oncol. 2002;3(8):487-497. doi:10.1016/S1470-2045(02)00818-5

41. van der Zee J, Gonzalez Gonzalez D, van Rhoon GC, van Dijk JD, van Putten WL, Hart AA. Comparison of radiotherapy alone with radiotherapy plus hyperthermia in locally advanced pelvic tumours: a prospective, randomised, multicentre trial. Dutch Deep Hyperthermia Group. Lancet. 2000;355(9210):1119-1125. doi:10.1016/S0140-6736(00)02059-6

42. Schilling D, Kuhnel A, Konrad S, et al. Sensitizing tumor cells to radiation by targeting the heat shock response. Cancer Lett. 2015;360 (2):294-301. doi:10.1016/j.canlet.2015.02.033 
43. Milanovic D, Firat E, Grosu AL, Niedermann G. Increased radiosensitivity and radiothermosensitivity of human pancreatic MIAPaCa-2 and U251 glioblastoma cell lines treated with the novel Hsp90 inhibitorNVP-HSP990. Radiation Oncol. 2013;8(1):42. doi:10.1186/1748-717X-8-42

44. Myerson RJ, et al. Simultaneous superficial hyperthermia and external radiotherapy: report of thermal dosimetry and tolerance to treatment. Int J Hyperthermia. 1999;15(4):251-266. doi:10.1080/ 026567399285639

45. Datta NR, Ordóñez SG, Gaipl US, et al. Local hyperthermia combined with radiotherapy and-/or chemotherapy: recent advances and promises for the future. Cancer Treat Rev. 2015;41(9):742-753. doi:10.1016/j.ctrv.2015.05.009

46. Espinosa A, Curcio A, Cabana S, et al. Intracellular Biodegradation of Ag Nanoparticles, Storage in Ferritin, and Protection by a Au Shell for Enhanced Photothermal Therapy. ACS Nano. 2018;12 (7):6523-6535. doi:10.1021/acsnano.8b00482

47. Holmila RJ, Vance SA, King SB, Tsang AW, Singh R, Furdui CM. Silver Nanoparticles Induce Mitochondrial Protein Oxidation in Lung Cells Impacting Cell Cycle and Proliferation. Antioxidants. 2019;8 (11):552. doi:10.3390/antiox8110552

48. AshaRani PV, Mun GLK, Hande MP, Valiyaveettil VS. Cytotoxicity and Genotoxicity of Silver Nanoparticles in Human Cells. ACS Nano. 2009;3(2):279-290. doi:10.1021/nn800596w
49. Fahrenholtz CD, Swanner J, Ramirez-Perez M, Singh RN Heterogeneous Responses of Ovarian Cancer Cells to Silver Nanoparticles as a Single Agent and in Combination with Cisplatin. $J$ Nanomater. 2017;2017:5107485. doi:10.1155/2017/5107485

50. Huo L, Chen R, Zhao L, et al. Silver nanoparticles activate endoplasmic reticulum stress signaling pathway in cell and mouse models: the role in toxicity evaluation. Biomaterials. 2015;61:307-315. doi:10.1016/j.biomaterials.2015.05.029

51. Gopisetty MK, Kovacs D, Igaz N, et al. Endoplasmic reticulum stress: major player in size-dependent inhibition of P-glycoprotein by silver nanoparticles in multidrug-resistant breast cancer cells. J Nanobiotechnology. 2019;17(1):9. doi:10.1186/s12951-019-0448-4

52. Laszlo A, Fleischer FI. Heat-Induced Perturbations of DNA Damage Signaling Pathways are Modulated by Molecular Chaperones. Cancer Res. 2009;69(5):2042-2049. doi:10.1158/0008-5472.CAN-08-1639

53. Oei AL, Vriend LE, Crezee J, Franken NA, Krawczyk PM. Effects of hyperthermia on DNA repair pathways: one treatment to inhibit them all. Radiat Oncol. 2015;10:165.

54. Keblinski P, Cahill DG, Bodapati A, Sullivan CR, Taton TA. Limits of localized heating by electromagnetically excited nanoparticles. J Appl Phys. 2006;100(5):054305.
International Journal of Nanomedicine

\section{Publish your work in this journal}

The International Journal of Nanomedicine is an international, peerreviewed journal focusing on the application of nanotechnology in diagnostics, therapeutics, and drug delivery systems throughout the biomedical field. This journal is indexed on PubMed Central, MedLine, CAS, SciSearch ${ }^{\circledR}$, Current Contents ${ }^{\circledR} /$ Clinical Medicine,

\section{Dovepress}

Journal Citation Reports/Science Edition, EMBase, Scopus and the Elsevier Bibliographic databases. The manuscript management system is completely online and includes a very quick and fair peer-review system, which is all easy to use. Visit http://www.dovepress.com/ testimonials.php to read real quotes from published authors. 